INTERNATIONAL JOURNAL OF LAW: "LAW AND WORLD"

August 2021 (№18). Volume 7; Issue 3; Page No. 6-11

https://doi.org/10.36475/7.3.1

www. lawandworld. ge

ISSN: 2346-7916 (Print); ISSN: 2587-5043 (Online)

https://creativecommons. org/about/cclicenses/ (Licensed under: CC BY-SA)

\title{
CONSTITUTIONALITY OF DISASTER MANAGEMENT ACT, 2005 ON THE TOUCHSTONE OF FEDERALISM DURING COVID-19 IN INDIA
}

\author{
Dhruvin N. Dosani \\ Student of LL.M. Insttute of Law, Nirma University, India \\ DR. Tarkesh J. Molia \\ Associate Professor, Institute of Law, Nirma University, India \\ DR. Vikash Kumar Upadhyay \\ Assistant Professor, Institute of Law, Nirma University, India
}

\begin{abstract}
As per $7^{\text {th }}$ Schedule of Constitution of India, 1950 there is sub-division of three lists namely Union list, State list and Concurrent list, which gives a detailed insight of powers of law making with both Centre and State in our country. Due to this both Centre and State have their exclusive domain wherein they can exercise their law-making power. During this exercise of power, which has been so specifically demarcated, can there be dispute of any kind? Answer is yes, Centre has often encroached upon exclusive domain of State subject matters by passing laws on such subject(s). The prominent example of it is the exercise of power under the Disaster Management Act, 2005 which came to be invoked by Centre for issuing guidelines binding on States in light of prevention of global pandemic being COVID-19. Public health and sanitation are a specific field of legislation under Entry 6 of List II, implying that States have exclusive power to legislate upon matters wherein public health is an issue, however despite of that Central Government laid down an array of guidelines during the COVID-19 pandemic directing States to enforce those guidelines. In this article, the main focus will be regarding constitutionality of those guidelines issued by Centre and the interpretation laid down by the Judiciary in regards to similar incidents. Furthermore, the history of enactment of Disaster Management Act, 2005 and how the powers exercised under the guise of it, will be analyzed in order to arrive at a reasonable conclusion in relation to the present issue. Moreover, upon this premise of issuance of guidelines by Centre under the DMA Act, 2005, the Indian Federalism would be discussed upon the touchstone of judgements delivered by Hon'ble Supreme Court in said regard and by briefly comparing same with other federal jurisdictions such as United States. The entire Paper will be a blend of descriptive, historical, comparative and analytical approach.
\end{abstract}

KEYWORDS: COVID-19, Federalism, Disaster Management

\section{INTRODUCTION}

The world was not prepared for a pandemic like COVID-19 and it came as a huge blow financially and even otherwise for everyone who were just carrying on with their usual lives. No one anticipated something like this, and it is even strange to say now that a virus has halted the activities going around the entire globe for almost one year since March-2020. Specifically speaking, as like others, India was also not ready for something like this and since the first nationwide lockdown, the Government is trying to curb down the spread of virus as effectively as possible. Some good news in this situation is that presently, vaccines are invented and 
have been started to get distributed to the public by the Government. What is now required to be understood in this scenario, is the legal backing of decisions undertaken by the Government during the pandemic. Moreover, India is a federal country like United States, where powers are distributed between State and Centre and in this premise, it is important to understand the legislative and constitutional relations between Centre and Sate during the time of a disaster like COVID-19. In short, the constitutionality of guidelines issued by Central Government through Home Ministry during pandemic will be reviewed upon the touchstone of Constitutional provisions in alignment with the federalism prevailing in India. On 24.03.2020, Disaster Management Act, 2005 was invoked wherein the National Disaster Management Authority under the guise of Section 6(2)(i) directed all the respective State Government to impose lockdown for a period of 21 days initially'. The same came to be extended from time to time looking at the situation of COVID-19. Now, the interesting part here is that Public health and sanitation are a specific field of legislation under Entry 6 of List II, of Schedule VII of the Constitution, implying that States have exclusive power to legislate upon matters wherein public health is an issue. So, did Centre have powers to issue guidelines making it mandatory for States to execute the same? Moreover, isn't this kind of attitude fatal to federal structure of India? These are essentially the issues which will be discussed in the present article.

\section{FEDERALISM IN INDIA}

It is important to understand the federalism in Indian in order to assess the situation of COVID-19 and Centre State relations. Firstly, Article 1 of the Indian Constitution provides that India shall be union of States. What this means is that unlike other federal countries, India was a product of Unitary system being dissolved into a federal system. So here, the states did not come together in order to form a Union, rather it was vice-versa. In this background following are the features of Indian federalism:

1. In Indian system, there is a dual polity meaning there are both State and Central governments.

2. Schedule VII of Indian Constitution enumerates three lists wherein powers are divided between State and Central Government. There is State List (Conferring exclusive powers to State), Central List (Conferring exclusive powers to

1 https://prsindia.org/files/covid19/notifications/143.IND Citizens_Order_Lockdown_Mar_24.pdf.
Centre) and Concurrent List (Conferring powers on both State and Centre). However, here it is pertinent to mention that residuary powers in India lie with the Central Government. ${ }^{2}$

3. In India there is an independence of Judiciary from Legislative and Executive. As per Article 50 of the Constitution it is specifically provided that Judiciary shall be independent of Executive. Also, Article 124 establishes provision for Supreme Court of India, which in turn implies its independence.

4. Indian Constitution is a rigid constitution wherein Article 368 provides for certain amendments to the Constitution requiring special majority. Moreover, as per Kesavananda Bharti Judgement $^{3}$, basic features of Constitution cannot be even amended under the guise of Article 368 by the Parliament.

5. Indian Constitution is a written constitution unlike that of countries like United Kingdom.

6. In India there is supremacy of Constitution, which implies that it is the supreme law of land. In fact in the case of Minerva Mills \& Ors. V. UOI \& Ors. ${ }^{4}$, Hon'ble Supreme Court held that Government, Legislature, Executive and Judiciary are all bound by the Constitution and no one is above or beyond the Constitution.

\section{JUDICIARY'S VIEW OF INDIAN FEDERALISM?}

Not going into details, succinctly stating judiciary's view, the most important one was delivered by Hon'ble Supreme Court in the case of Keshavananda Bharti wherein it termed 'Federalism' as a basic structure of Indian Constitution which cannot be amended by the Parliament. Post that J Krishna lyer in the case of Shamser V. State of Punjab5held that "The law of our Constitution, any student of Indian political history and of comparative constitutional systems will agree, is partly eclectic but primarily an Indo-Anglian version of the Westminster model with quasi-federal adaptations, historical modifications, geopolitical mutations and homespun traditions-basically a blended brew of the British parliamentary system, and the Government of India Act, 1935 and near-American, nomenclature-wise and in some other respects". After that,

Article 248 of the Constitution of India, 1950 read with Entry 97 of List I of Seventh Schedule of Constitution. AIR 1973 SC 1461.

1981 SCR (1) 206.

1975 SCR (1) 814 
J. Bhagwati in the case of UOI V. Sankalchand ${ }^{6}$ mentioned that Indian Constitution can be described as Federal or Quasi-Federal.

However, apart from the aforesaid judgements, true nature of Indian Federalism could be identified from the earliest case of State of West Bengal V. $\mathrm{UOI}^{7}$ wherein Hon'ble Supreme Court discussed the nature of Indian federalism in detail. Hon'ble Supreme Court held that Indian Constitution is not actually and completely Federal in character. It was held that basis of power distribution as per the Seventh Schedule of Indian Constitution is that local problems be assessed by the States and residue of those are left with the Centre. Moreover, it was held that absolute sovereignty does not rest with States in India and Parliament is competent to legislate upon the subjects as mentioned in the List I and III of the Indian Constitution, even if some other entry of List II mentions similar content.

From the aforesaid, it can be said that nature of Indian Constitution is a federal constitution leaning towards Centre or having strong Centre or Quasi-Federal. This is so, because Centre herein has residuary powers and the fact that the structure of Indian politics in general grants more power to Centre than the States. This can be seen from constitutional assembly debates wherein Jawaharlal Nehru, who is the 1st PM of India said "it would be injurious to the interests of the country to provide for a weak central authority which would be incapable of ensuring peace, of coordinating vital matters of common concern and of speaking effectively for the whole country in the international sphere"8. Hence, from this we can say that India has always been a country with Strong Centre which was also the vision of the constitutional makers of the country.

\section{DISASTER MANAGEMENT ACT, 2005}

The preamble to Disaster Management Act, 2005 (in short "The Act") provides that it is "An Act to provide for effective management of disasters". This act came into force on 23.12.2005. Basically, The Act was brought in the wake of Tsunami which took place on 26.12.2004 and it was enacted under List III Entre 23 of Schedule 7. Reason for this law to be enacted under Concurrent List was to provide States with a liberty to formulate their own laws in order to deal with State

\footnotetext{
61978 SCR (1) 423.

$7 \quad 1964$ SCR (1) 371.

8 Volume V, 20.08.1947, Constitutional Assembly Debates.
}

Specific situation. Section 3 of The Act makes provision for establishment of a National Disaster Management Authority ("NDMA") which is a National authority with Prime Minister as a chairperson. Section 5 bestows Central Government a duty to provide NDMA with officers and employees as it deems fit. Section 6 of The Act empowers NDMA to lay down guidelines and policies in order to tackle the disaster. Similarly, the Act also provides for establishment of State and District level disaster management authorities which are required to work in co-ordination with NDMA. Central Government and NDMA are also conferred with sizeable powers under the Act wherein, for the purpose of management of disaster, any directions or guidelines can be issued by the Centre and this power is of overriding nature by-passing any other law existing or having force in India. ${ }^{9}$ These slews of directions could be issued to mandate all State Governments, State Authorities etc. to follow and comply with them. As per these provisions, State Government may make their own laws and issue directions not mentioned by NDMA but they cannot deviate from directions already issued by National Authority and only leeway given to them is to impose harsher restrictions looking at local situation.

\section{IS THE DISASTER MANAGEMENT ACT, 2005 A TOP DOWN APPROACH?}

Looking at the provisions of the Act, it can be implied that it leans towards more Top Down approach with Central Government having extensive powers under the Act. These powers are so wide that State Governments irrespective of any law in force, are required to comply with the directions given by Centre. However, if the purpose of the Act is looked upon, it aims towards the effective management of disaster. In a situation like COVID-19 wherein it is of extreme importance that State and Centre practice co-operative federalism, the Act comes in as a rescue and it provides for a proper combination of Top Down and Bottom Up approach. To understand the previous statement, we have to understand the same keeping in mind the premise of aforesaid judgements and characteristics of Indian Federalism. As seen from above, India is not a truly federal country for the reason that States here do not possess their own separate Constitution and the fact that it can be amended at the instance of Centre and not States.

Hence, looking at aforesaid, we can examine The Act, as to whether it is constitutionally correct in light of

9 Section 35, 62 and 72 of The Act. 
Indian federalism or not? The Act provides for States to develop and form SDMA which is akin to NDMA, as per this the plan of every individual state is to be adopted and finalized by SDMA and not NDMA. This shows the flexibility given under the act respecting their federal nature so that they can impose provisions in the plan as per their local situation irrespective of guidelines rendered by Center. However, it is to be kept in mind that directions of NDMA are to be strictly complied with and it is only the addition to those directions that are permitted under The Act. Therefore, there is a mixture of top down and bottom-up approach because the states are given powers to handle their respective situation while being in consonance with the guidelines issued by the Centre in the said regard. The pandemic of coronavirus brought about an absolute halt for the entire nation due to which it was of extreme importance that Centre issue guidelines which are relevant for the entire country and states can alter those guidelines looking at vulnerability of their particular region. Now as we have seen from the judgements stated above that the federal structure of Indian constitution leans toward having a strong Centre and in that premise The Act which provides for Centre to issue guidelines during a disaster is constitutionally valid and also provides an instance for cooperative federalism to exist in India. Also, the powers given to NDMA under The Act is not showcase of dominance of Centre over States, but rather it shows the responsibility undertaken by the Centre to provide necessary and uniform guidance in a situation like this, which is a global pandemic, and allowing States to micromanage at their own level, which was exactly the vision of Constitutional framers of the nation. In this the Central Government has already provided adequate assistance to the States requiring financial aid, military forces and requisite materials, showing that the current federal structure of India, is appropriate and effective. Moreover, if there are uniform guidelines for States to follow, it makes their job easier to amend those guidelines as they already have a pro forma of same ready. COVID-19 is a universal situation wherein almost all the nations have taken similar precautions to contain the spread of virus; hence, in this situation, the guidelines by Centre under DMAAct, 2005 were in complete alliance with the Constitutional framework of India.

Moreover, it is important to note that unlike declaration of emergency under Article 352 of the Constitution of India, 1950, wherein except Article 20 and 21 , other fundamental rights may be suspended by the Government, in the present situation the Centre cannot pass any guideline which affects either of the Fundamental rights of the citizens and upon passing of any such guideline a person may approach the High Court under Article 226 and similarly Supreme Court under Article 32 of the Constitution of India, 1950.

For instance, guideline/s for lockdown and taking appropriate measures including detention of persons who are violating the guidelines can be termed to be in consonance with the object of the said act as the purpose of those guidelines is to contain or mitigate the disaster (COVID-19). However, guidelines passed shall also not violate any of fundamental rights of the citizens in any manner such as Capital Punishment for violation of guidelines or levy of excessive fine against violators. The similar circulars have been issued by nations such as Saudi Arabia and Australia recently. This makes it clear that Centre do not have unfettered powers under The Act and their only job is to provide a necessary framework for States to follow and comply.

\section{CONCLUSION}

The issuance of guidelines under DMAAct, 2005 is constitutionally valid and same cannot be challenged as India unlike United States do not follow strict Federalism. Here, the Centre has absolute power to legislate on any subject in List-I and III along with having residuary powers. As Disaster is not included in either list, Central Government framed Disaster Management Act, 2005 under Entry 97 of List I making the said act competent and the content of The Act in consonance with the Indian Quasi Federal nature. Moreover, the role of Centre has been pivotal during this crisis and considering the same, it was important to have uniform guidelines for each State to follow without which, every State would have made different arrangements and difference in spread of virus in States would be huge in numbers.

\section{BIBLIOGRAPHY:}

1. H. M. Seervai, Constitution Law of India: A Critical Commentary, (N. M. Tripathi ed., Bombay 1975).

2. D.D. Basu, Shorter Constitution of India (13th ed., 2001).

3. Granville Austin, The Indian Constitution - Cornerstone of a Nation (2nd ed. 1999). 